\title{
Heavy Metal Concentrations in Sediment Cores from Different Mangrove Forests in Da Loc Commune, Hau Loc District, Thanh Hoa Province, Vietnam
}

\author{
Tran Thi Minh ${ }^{1, *}$, Nguyen Tai Tue ${ }^{2,3}$, Tran Dang Quy ${ }^{2,3}$, Lee Jong-Un ${ }^{1}$ \\ ${ }^{I}$ Department of Energy and Resources Engineering, Chonnam National University, Gwangju, Korea \\ ${ }^{2}$ Faculty of Geology, VNU University of Science, 334 Nguyen Trai Street, Thanh Xuan, Hanoi, Vietnam \\ ${ }^{3}$ VNU Key Laboratory of Geoenvironment and Climate Change Response, \\ 334 Nguyen Trai, Thanh Xuan, Hanoi, Vietnam
}

Received 19 June 2018

Revised 09 August 2018; Accepted 16 August 2018

\begin{abstract}
In order to clarify heavy metal concentration profiles in different mangrove forest ages, four sediment cores (up to $100 \mathrm{~cm}$ in depth) were collected and tested for their physicochemical characteristics ( $\mathrm{pH}$, Eh, organic matters and grain size) and heavy metal concentrations. Results showed that mangrove sediments were composed mainly of sandy silt, silty sand, silt, sandy mud and mud. The average mud content in the sediment cores continuously increased with mangrove forest ages from one, nine, nineteen and twenty years old, whereas the mud content highly fluctuated with the core depth. $\mathrm{pH}$, Eh and organic matter content implied that the sedimentary depositional environments were classified as weak alkaline and anaerobic. The $\mathrm{Cu}$ and $\mathrm{Zn}$ concentrations in the sediment cores from the intertidal zone exceeded the TEL values in Canadian Interim Marine Sediment Quality Guideline (ISQGs) values, while, $\mathrm{Pb}$ concentration exceeded the PEL level. When compared with National Technical Regulation on Sediment Quality QCVN43:2012/BTNMT, sediment samples were polluted by $\mathrm{Cu}$ and $\mathrm{Pb}$.
\end{abstract}

Keywords: Mangrove sediments, heavy metals, intertidal, Da Loc.

\section{Introduction}

Mangrove forests are growing in the intertidal zones, forming major ecosystems of subtropical and tropical coastal lines. The mangrove ecosystems provide a valuable

\footnotetext{
* Corresponding author. Tel.: 84-1048850515.

Email: minhminhtran94@gmail.com

https://doi.org/10.25073/2588-1094/vnuees.4261
}

resources and ecosystem services including nursery grounds for fishes and birds, a renewable resource of fuels and protection of coastlines from erosion, storms and tsunamis $[1,2]$. Therefore, mangrove system plays a key role in development of socio-ecological systems of coastal area [3]. However, mangrove forest ecosystems are also considered as a filter to trap the pollutants that are transported from the continents to oceans [4]. For example, a 
mangrove forest situated adjacently urban regions [5], thus it was potentially used as an experiment to monitor the influence of economic activities, industrial waste, agricultural runoff, domestic garbage dumps, and aquaculture activities in a long period [6]. This study showed that heavy metal concentrations of copper $(\mathrm{Cu})$, lead $(\mathrm{Pb})$, zinc $(\mathrm{Zn})$, manganese $(\mathrm{Mn})$, cadmium $(\mathrm{Cd})$, chromium $(\mathrm{Cr})$ tended to increase from bottom to surface layers of mangrove sediment cores [7]. It should be noted that the flexibility and toxicity of heavy metals in mangrove ecosystems are highly influenced by their concentration levels and the availability and geochemical conditions. Through the food chains, heavy metals can be migrated from sediments into plants and accumulated in the consumers in mangrove ecosystems [8-9].

The mangrove forest is located in $\mathrm{Da} \mathrm{Loc}$ commune, Hau Loc district, Thanh Hoa province, north central coastline of Vietnam (Fig. 1). The mangrove forest covers a total area of 372 ha, being dominated by mangrove species of Kandelia candel, Sonneratia casionaris and Caegiceras corniculatum. The eldest mangrove in Da Loc has been initially planted around 27 years ago, followed by $24,19,15,12,9,5,4,3,2$ and 1 years ago. The key purposes of the mangrove plantation area were to increase the adaptation of coastal population and to reduce vulnerability from storms, sea-level rise, floods and other coastal disasters. Moreover, mangrove forests can supply rich habitats for fishes, shrimps, crabs, and other invertebrate to raise economic development of coastal communities. Several studies that have focused on assessing the heavy metal concentration in mangrove sediments in Vietnam [4,7,10-12]. In Da Loc commune, many studies were conducted to focus examining the mangrove social-ecological system dynamics [13,14]; impacting of aquaculture on social networks in mangrove systems [15] and adapting of natural disasters and contributing to climate change by mangrove [16]. However, there is virtually no study to focus on heavy metal concentrations in mangrove sediments. Therefore, classify on heavy metals concentration in mangrove sediment is high appreciated not only for mangrove environmental assessments but also for human activities surrounding coastal zone, specially, in Da Loc area.

As the result, the aims of the present study are to clarify environmental geochemical characteristics of mangrove sediment cores and to understand the heavy metal concentration variations in four different ages of mangrove forests in Da Loc commune.

\section{Materials and methods}

\subsection{Sampling}

The fieldwork was carried out in February, 2016. The sampling sites are shown in Fig. 1. Four sediment cores were collected in different distances from the sea to mangrove forest sediment. The sediment core (DL01) was collected from one year mangrove forest, and was located in the sea edge and significantly affected by the sea wave. Sediment core (DL09) was collected from the nine years-old mangrove forest that distributed in the middle zone between sea edge and sea dyke. Sediment core (DL19) was gathered in 19 years-old mangrove forest that was adjacent to aquaculture pond. The sediment core (DL27) was collected from 27 years-old mangrove forest that was on the right bank of the Len estuary, where was also influenced by wave power and stream flow (Fig.1). All the sediment cores (100 cm in length) were collected using a peat corer following the method of Tue [17]. Immediately after collection, sediment cores were placed in PVC tubes, sealed in the aluminum foils in order to minimize the gas exchange, then placed in a cooler, and processed within 24 hours after collection. The sediment cores were sliced into different intervals as following: an interval of $5 \mathrm{~cm}$ between $0-50 \mathrm{~cm}$ in depth and of $10 \mathrm{~cm}$ from $50-100 \mathrm{~cm}$ in depth. For each sediment core, a total of 15 subsamples was divided and immediately placed in PE bags, stored at $2-5^{\circ} \mathrm{C}$ in the icebox and transported to the laboratory for further analysis. 


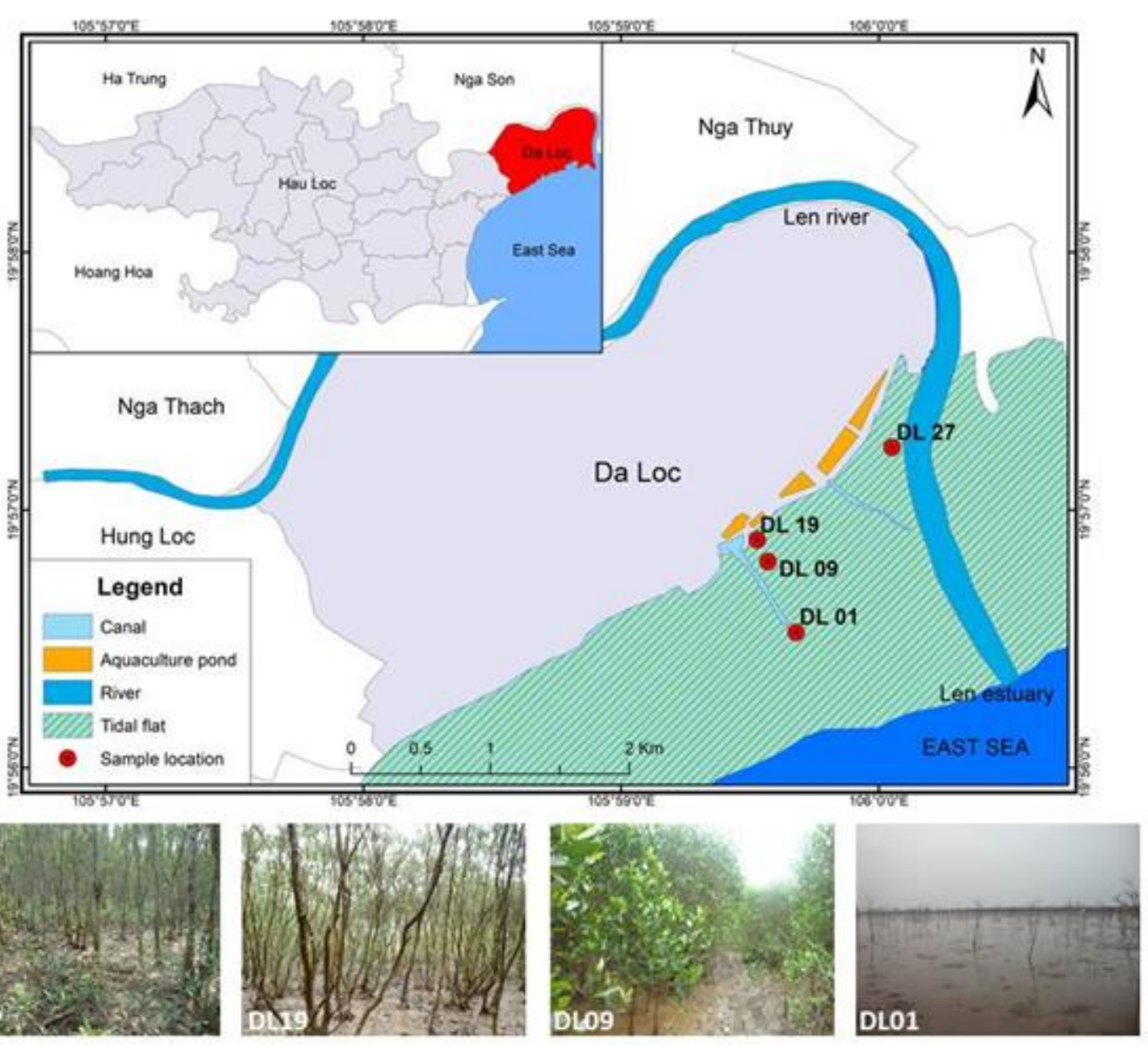

Fig. 1. The map shows the study area and sampling sites of four sediment cores DL01, DL09, DL19 and DL27 in Da Loc mangrove forest. The photos show the characteristics of four mangrove forest.

\subsection{Analytical methods}

Eh value of the sediments was measured immediately using a portable platinum meter (Hana HI 9829-00042). For pH measurement, an amount of $10 \mathrm{~g}$ of the pulverized sediments was poured within $50 \mathrm{ml}$ water in a polyethylene bottle $(100 \mathrm{ml})$ and then mixed using a shaker for an hour. $\mathrm{pH}$ value was then measured using a portable meter. The sediment grain sizes were determined using an automatic laser diffraction particle size analyzer (HORIBA, LA-950V2) with the measurement range of 0.01-3000 m. Approximately $0.02 \mathrm{~g}$ of original sediment samples was put into the LA-
950V2 for determining the grain size distribution during three minutes.

The sediment organic matter content (OM) was determined through the loss on ignition method. An amount of two grams sediments were combusted at $100^{\circ} \mathrm{C}$ for two hours to remove water inside the sample. After cooling we measured $m_{1}$ weight and re-combusted at $550^{\circ} \mathrm{C}$ in a temperature-monitored muffle furnace for $5 \mathrm{~h} \quad\left(\mathrm{~m}_{2}\right.$ weight $)$. The $\mathrm{OM}$ was determined by an equation:

$$
\mathrm{OM}(\%)=\left[\left(\mathrm{m}_{1}-\mathrm{m}_{2}\right) * 100\right] / \mathrm{m}_{1}
$$

Where in $m_{1}$ and $m_{2}$ is the sample weight pre- and post- combustion, respectively. 
A total of 19 samples of four sediment cores were chosen from the sediment layers of $0-5 \mathrm{~cm}$, $25-30 \mathrm{~cm}, 45-50 \mathrm{~cm}, 70-80 \mathrm{~cm}$ and $90-100 \mathrm{~cm}$ for analyzing heavy metals concentration. An amount of 20 grams was first dried at $40^{\circ} \mathrm{C}$ in an electric oven for $72 \mathrm{~h}$. The dried sediment samples were ground into fine powder using an agate mortar and pestle. Then, an amount of 0.1 g pulverized sediment was treated with a mixed solution of $3 \mathrm{ml} \mathrm{HNO}_{3} 65 \% ; 5 \mathrm{ml} \mathrm{HCl} 37 \%$ and $1 \mathrm{ml} \mathrm{HF} \mathrm{48 \%} \mathrm{in} \mathrm{a} \mathrm{Teflon} \mathrm{vessel} \mathrm{and} \mathrm{digested} \mathrm{in}$ a microwave system for an hour to transfer solid sample into liquid type. A volume of $1 \mathrm{ml}$ liquid sample and mixed acid solution of $1 \mathrm{ml}$ $\mathrm{HCl} 10 \%, 1 \mathrm{ml} \mathrm{CH}_{3} \mathrm{COONH}_{4} 10 \%$ and $7 \mathrm{ml} \mathrm{DI}$ water was mixed and shaken in a beaker. The concentrations of copper $(\mathrm{Cu})$, manganese $(\mathrm{Mn})$ and zinc $(\mathrm{Zn})$ were determined using an Atomic Absorption Spectrophotometer (AAS, 240FSAA, Agilient) system. For cadmium (Cd) and lead $(\mathrm{Pb})$ analyzed using the AAS coupled with a graphite tube atomizer (GTA 200).

\section{Results}

\subsection{Particle size analysis}

The sediment types of 60 sediment samples collected at 4 sites DL01, DL09, DL19 and DL27 were identified following Folk's classification [18] (Fig. 2a). The sediment types were divided based on sediment grain size distribution. Results showed that mangrove sediments were classified into sandy silt, silty sand, silt, sandy mud and mud. Most sediments in core DL01 were sandy mud, silty sand and sandy silt, while sediments in core DL27 were mud and silt. Approximately $93.3 \%$ and 73.3 $\%$ sediment samples in cores DL09, DL19 were classified into sandy silt. The depth variation of mud content in four sediment cores was shown in Fig. 2b. For sediment core DL01, mud proportion varied from 49.58 to $87.62 \%$ with a mean of $62.13 \%$. The mud proportion was less variation between surface sediment to $35 \mathrm{~cm}$ in depth and reached to value of $61 \%$. The mud proportion displayed a significant increase from 50 to $70 \mathrm{~cm}$ in depth, with a peak of $87.62 \%$ at the depth of $60 \mathrm{~cm}$ and was slightly fluctuated to the core bottom. For the sediment core DL09, the mud proportion ranged from 59.1 to $81.2 \%$, being the lowest among the sediment cores. A considerable fluctuation of mud proportion was observed in sediment core DL19, with a range of $42.19-97.12 \%$. For the sediment core DL27, the mud proportion was displayed a similar fluctuation pattern with the DL19 between sediment surface and $40 \mathrm{~cm}$ in depth. The mud content was markedly decreased at the depth below $45 \mathrm{~cm}(38.12 \%)$ and then slightly increased to the core bottom $(71.2 \%)$.
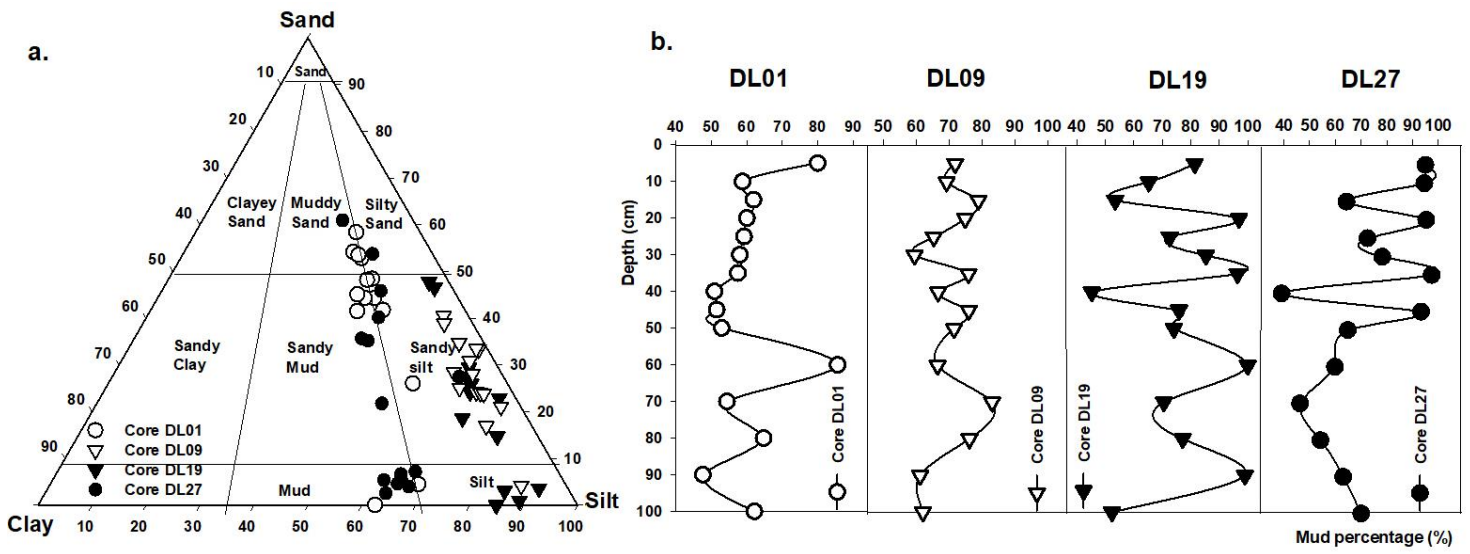

Fig. 2. a. Sediment types identified by the relative percentages of sand, clay and silt proportion in four sediment cores; b. Depth variations of mud proportion in four sediment cores. 


\section{2. $p H$, Eh value and organic matter (OM) content}

The mean $\mathrm{pH}$ values of four sediment cores ranged from 6.43-7.5. $\mathrm{pH}$ values markedly decreased from sediment core DL01 (7.82) to DL27 (7.07) and increased gradually from DL09 to DL19. The variation with a depth of $\mathrm{pH}$ values were shown in Fig. 3a. Overall, $\mathrm{pH}$ values were not varied with depth in all sediment cores. $\mathrm{pH}$ value in the sediment layer $(0-20 \mathrm{~cm})$ were lower than in the bottom layer. $\mathrm{pH}$ values in the sediment core of elder planted mangrove forests were more stable than young planted mangrove forests.

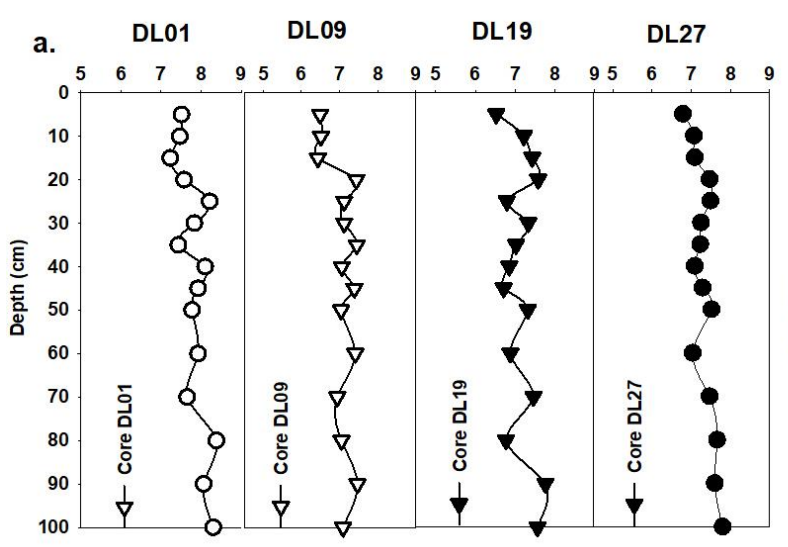

The mean values of redox potential (Eh) gradually increased from DL01 to DL09, DL19 and DL27 and ranged from -107.6 to -142.69 $\mathrm{mV}$ (Fig. 3c). Eh values considerably varied with the depth (Fig 3d). For the core DL01, Eh values increased markedly from -124.15 to $22.36 \mathrm{mV}$, then decreased gradually to the depth around $20 \mathrm{~cm}(-117.32 \mathrm{mV})$ and tended to be slightly varied to core bottom. There were reduction of Eh values between $0-15 \mathrm{~cm}$ in depth of the sediment cores DL09 and DL19 while Eh value displayed a slight fluctuation from -41.33 to $-92.18 \mathrm{mV}$ for the sediment core DL27. In the middle of core, Eh values changed insufficiently and more stability at the bottom of the cores.

Fig. 3. The fluctuation of $\mathrm{pH}$ and Eh values in the depth marked a, b respectively.

Table 1 showed the mean, median, standard deviation, minimum, maximum and coefficient of variation values of sediment $\mathrm{OM}$ in four sediment cores. The mean $\mathrm{OM}$ ranged from 8.14 to $13.3 \%$ with the minimum and maximum value was $5.81,22.15 \%$, respectively. The OM in the layers between $0-50 \mathrm{~cm}$ was higher than layers in the core bottom (Fig. 4). From sediment core DL01 (early planted mangrove) to DL27 (highest development planted mangrove), the OM content tended to increase continuously.
Table 1. Mean, median, standard deviation, minimum, maximum, coefficient of variation values of organic matter content in sediment cores $(n=60)$

\begin{tabular}{lllll}
\hline & DL 01 & DL 09 & DL 19 & DL 27 \\
\hline Mean & 8.14 & 9.97 & 11.79 & 13.63 \\
Median & 8.23 & 10.27 & 10.35 & 13.10 \\
Standard & 1.60 & 1.51 & 5.70 & 2.91 \\
Deviation & & & & \\
Minimum & 5.81 & 6.98 & 6.93 & 8.79 \\
Maximum & 11.73 & 11.87 & 31.60 & 22.15 \\
CV & 19.59 & 15.12 & 48.29 & 21.35 \\
\hline
\end{tabular}




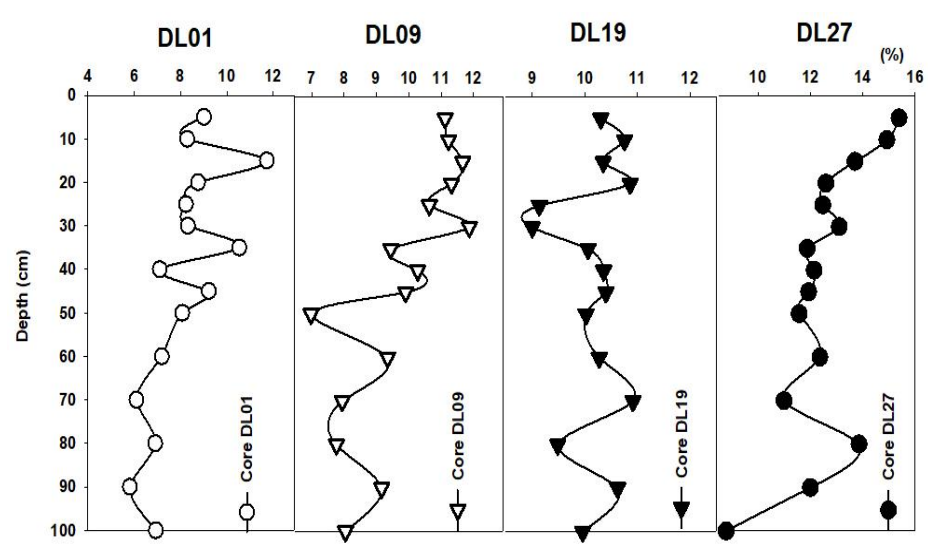

Fig. 4. Depth variation of organic matter content in mangrove of sediment cores.

\subsection{Heavy metals concentration}

Fig. 5 showed the concentrations of $\mathrm{Cu}$, $\mathrm{Mn}, \mathrm{Zn}, \mathrm{Pb}$, and $\mathrm{Cd}\left(\mathrm{mg} \mathrm{kg}^{-1}\right)$ in 19 sediment samples of DL01, DL09, DL19 and DL27. Results showed that manganese was the highest accumulation with $1,671.49 \mathrm{mg} \mathrm{kg}^{-1}$ and a mean value of $1,279.6 \mathrm{mg} \mathrm{kg}^{-1}$. Concentration of cadmium was the lowest concentration of 0.54 $\mathrm{mg} \mathrm{kg}^{-1}$, with a mean value of $0.45 \mathrm{mg} \mathrm{kg}^{-1}$. The concentration of $\mathrm{Zn}, \mathrm{Cd}, \mathrm{Pb}, \mathrm{Mn}$ and $\mathrm{Cu}$ gradually increased from cores DL01 to DL09 to DL19 and considerably declined in core DL27.

Heavy metal concentration displayed a significant variation in depth of $0-100 \mathrm{~cm}$ (Fig.6). The depth variation was similar with $\mathrm{Zn}, \mathrm{Pb}, \mathrm{Cd}$ concentration. There was a slight increase concentration of heavy metals from the surface to the bottom sediment core, with an exception for Cd concentration in core DL01, which considerably increased from $80-100 \mathrm{~cm}$ in depth. Simultaneously, grain size in the depth of sediment cores tended to be finer from silty sand, sandy silt to silt and mud (Fig. 6b). For $\mathrm{Cu}$ concentration, overall it slowly declined until $30 \mathrm{~cm}$ in depth and differently fluctuated among four sediment cores. While core DL01 and core DL09 gradually dropped through the depth of $80 \mathrm{~cm}$ and rose again until the bottom of sediment core, the fluctuation of core DL19, DL27 were inverse direction. An amount of accumulation of $\mathrm{Mn}$ in cores DL01, DL09, DL19 was reduced in the depth, however, the its concentration in core DL27 was significant growth from 401.23 to $1,625.12 \mathrm{mg} \mathrm{kg}^{-1}$ and then decrease down $1,237.64 \mathrm{mg} \mathrm{kg}^{-1}$.
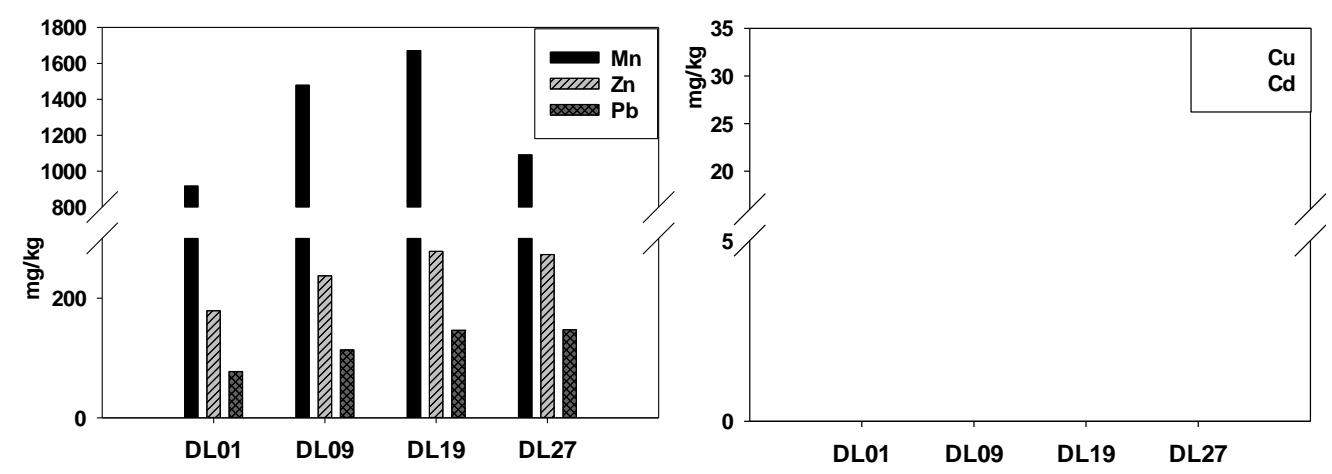

Fig. 5. Heavy metals (HMs) concentration in sediment cores. 

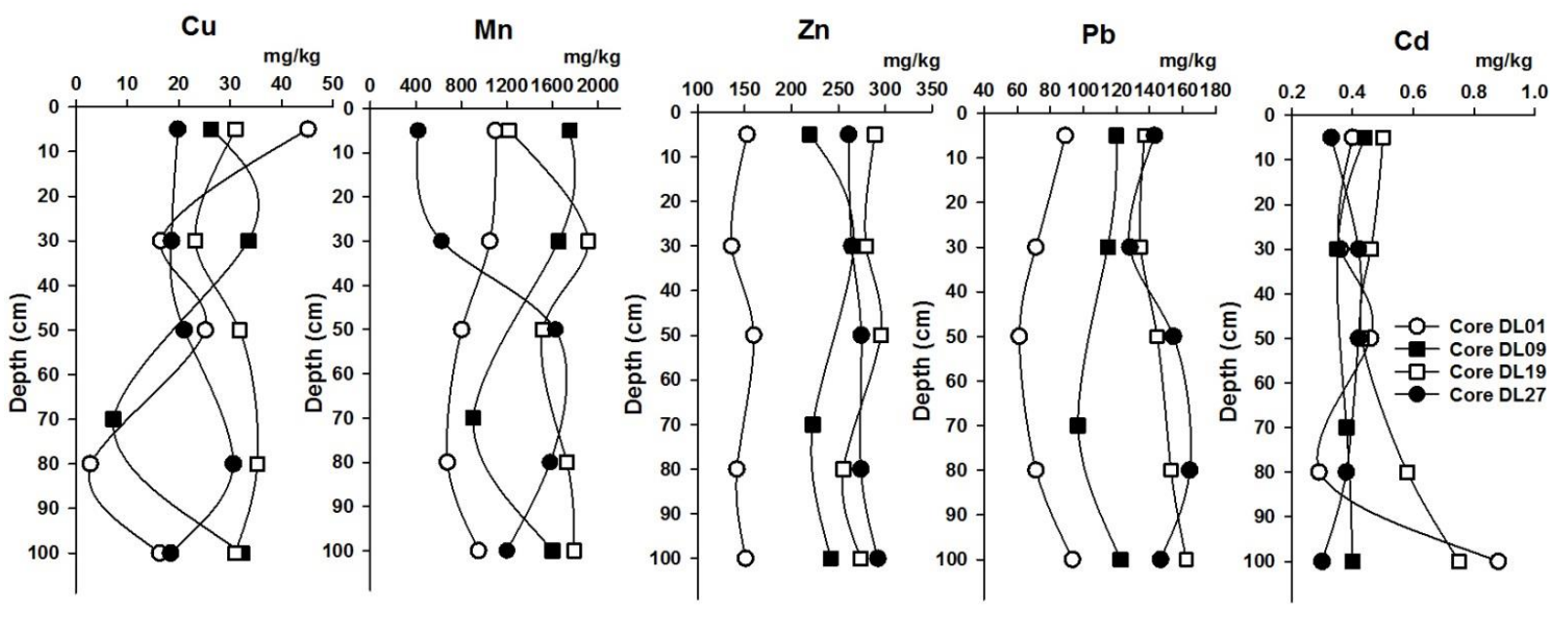

Fig. 6. Depth variation of heavy metal concentrations in mangrove sediment cores.

\section{Discussion}

\subsection{Factors affecting environmental} geochemistry and heavy metal concentrations in mangrove sediment cores

Mangrove forests are reported to be an important factor that effect to the characteristics and spatial distribution of suspended sediments [19]. In the present study, grain size composition showed that sediment grain sizes were highly homogenous through intertidal zone in mangrove forest (Fig. 2). Fine particle size composition was the highest in core DL27 and then gradually dropped down in core DL01. The results revealed that geomorphological characteristics were influenced the deposition pattern of suspended matter within mangrove forests [20]. Higher organic matter content in the sediment core from elder planted mangrove forest suggested that sedimentary organic matter could be originated dominantly from mangrove litters [7, 11]. The higher aboveground biomass of the 27 years-old mangrove forest tended to contribute a large organic matter sources into the sediment stratum and suspended organic matter transported from Len river [21].

The $\mathrm{pH}$ and Eh in sediment cores were two causative factors that could effects the availability and mobility of heavy metals. $\mathrm{pH}$ value of sediment samples presented the alkaline condition [22]. $\mathrm{pH}$ values results were similar with previous studies on sediment characteristics of mangrove from Bhatey, Sundarban, India and Bangladesh [11, 23-24]. In the present study, all Eh value were less than $100 \mathrm{mV}$, indicating for anaerobic environment [21]. In sediment layer $(0-15 \mathrm{~cm}$ in depth) of core DL01, Eh value markedly increased from 100 to $-25 \mathrm{mV}$ which was in contrast with other sediment cores. This distinction was probably original from the fluctuation of sediment salinity by sea wave activities [23]. On the other hand, the oxidation-reduction potential of sea water was controlled solely by oxygen system [25]. Therefore the difference in Eh value of DL01 with others suggested that the position of mangrove forests affected the geochemical characteristics of sediments.

Mn concentration in the present study was higher than sediments from Red Sea [26] and Punta Mala Bay, Panama [9]. $\mathrm{Cd}$ and $\mathrm{Cu}$ concentrations were not significantly different with other studies from Cienaga grande, Colombia [27]; Hawksbury, Australia [28-29]. The higher concentration of Mn (1,279.6 mg $\left.\mathrm{kg}^{-1}\right)$ and $\mathrm{Pb}\left(52.94 \mathrm{mg} \mathrm{kg}^{-1}\right)$ in the sediment core DL27 could suggest an influence of anthropogenic activities. It should be noted that heavy metals could enter into the coastal 
environments from different sources, including disposal of liquid effluents, runoff and leachates from domestic, industrial and agricultural activities [30-31]. In Da Loc coastal area, Len river could transport different pollutants to the downstream and incorporated in mangrove sediments. The sediment core DL27 was the closest with Len estuary and within a high density of mangroves, strong stems and roots, thus, it could accumulate higher heavy metals concentration. Moreover, these high heavy metal concentrations were interpreted by the affection of ocean wave strength, tidal regime, human activities (fishing and shrimp pond) and microbial activities [4].

Pearson correlation analysis showed a strong positive correlation coefficients between $\mathrm{Pb}$ and $\mathrm{Zn}(\mathrm{r}=0.79)$; moderated correlation coefficient between $\mathrm{Mn}$ and $\mathrm{Cu}(\mathrm{r}=0.51), \mathrm{Mn}$ and $\mathrm{Pb}(\mathrm{r}=0.57), \mathrm{Pb}$ and $\mathrm{OM}(\mathrm{r}=0.49)$; and weak correlation coefficient between $\mathrm{Mn}$ and $\mathrm{Zn}(\mathrm{r}=0.37), \mathrm{Pb}$ and $\mathrm{Cu}(\mathrm{r}=0.35), \mathrm{Cu}$ and mud $(r=0.38)$, Mn and mud $(r=0.30), Z n$ and OM $(r=0.30)$ (Table 2). The weak correlation among heavy metal concentrations demonstrated that they accumulated into mangrove sediments by various paths. The correlation pattern between heavy metals with mud and OM showed that they were factors affecting the concentration of $\mathrm{HM}$ in mangrove sediments [30,32]. The negative correlation between $\mathrm{Mn}, \mathrm{Cd}$ with OM content showed that OM content was not an important agent for accumulation in mangrove sediments in Da Loc area. Results was previously reported by Johan (2017) [33], who highlighted that the negative correlation between $\mathrm{Mn}$ and organic carbon indicated the important role of Mn-peroxidases in oxidative decomposition of recalcitrant organic matter.

\subsection{Quality assessment of heavy metals concentrations}

The concentration factor $(\mathrm{CF})$ was used to assess the heavy metal concentration affecting on the mangrove sediment core quality. The $\mathrm{CF}$ was calculated by the ratio between the heavy metal concentration in sediments of the present study and the background value. This method is considered to be an effective tool in monitoring the pollution over a period time [33-35]. In the present study, $\mathrm{CF}$ of $\mathrm{Mn}, \mathrm{Zn}, \mathrm{Pb}$ and $\mathrm{Cd}$ were $1.61,1.86,2.7,1.13$ respectively, classified as polluted components. In contrast, $\mathrm{Cu}$ concentration with $\mathrm{CF}$ value of 0.26 was not a polluted component.

Table 2. Pearson correlation coefficient matrix gave information between concentrations of HM parameters in sediments from Da Loc intertidal

\begin{tabular}{llllllll}
\hline & $\mathrm{Cu}$ & $\mathrm{Mn}$ & $\mathrm{Zn}$ & $\mathrm{Pb}$ & $\mathrm{Cd}$ & $\mathrm{Mud}$ & $\mathrm{OM}$ \\
\hline $\mathrm{Cu}$ & 1.00 & & & & & & \\
$\mathrm{Mn}$ & $\mathbf{0 . 5 1}$ & 1.00 & & & & & \\
$\mathrm{Zn}$ & 0.17 & 0.37 & 1.00 & & & & \\
$\mathrm{~Pb}$ & 0.35 & $\mathbf{0 . 5 2}$ & $\mathbf{0 . 7 9}$ & 1.00 & & & \\
$\mathrm{Cd}$ & 0.16 & 0.21 & 0.37 & 0.12 & 1.00 & & \\
$\mathrm{Mud}$ & 0.38 & 0.30 & 0.12 & 0.10 & 0.03 & 1.00 & \\
$\mathrm{OM}$ & 0.12 & -0.24 & 0.30 & $\mathbf{0 . 4 9}$ & -0.27 & -0.06 & 1.00 \\
\hline
\end{tabular}

OM: organic matter contents; Mud: total accumulations of silt and clay of sediment samples 
Table 3. Comparison the mean values of heavy metals concentration in the present study with Interim Marine Sediment Quality Guideline (ISQGs) of Canada and QCVN 43:2012/BTNMT

\begin{tabular}{lllllll}
\hline & ISQGs & $\mathrm{Cu}$ & $\mathrm{Mn}$ & $\mathrm{Zn}$ & $\mathrm{Pb}$ & $\mathrm{Cd}$ \\
\hline Mean & & $\mathbf{2 4 . 5 4}$ & $1,279.61$ & 242.27 & $\mathbf{1 2 1 . 5 3}$ & 0.45 \\
Minimum & & 2.80 & 420.20 & 136.10 & 61.30 & 0.30 \\
Maximum & & 45.20 & $2,104.00$ & 304.20 & 164.40 & 0.90 \\
Weakly contaminated & TEL & 18.70 & - & 124.00 & 30.20 & 0.70 \\
Moderately contaminated & 1,5*TEL & 28.05 & - & 186.00 & 45.30 & 1.05 \\
Heavily contaminated & 2*TEL & 37.40 & - & 248.00 & 60.40 & 1.40 \\
Extremely contaminated & 3*TEL & 56.10 & - & 372.00 & 90.60 & 2.10 \\
Affection level & & $\mathbf{1 0 8 . 0 0}$ & - & 271.00 & $\mathbf{1 1 2 . 0 0}$ & 4.20 \\
QCVN 43:2012/BTNMT & PEL & 108.00 & - & 271.00 & 112.00 & 4.20 \\
\hline
\end{tabular}

In comparison to Canadian Interim Marine Sediment Quality Guideline (ISQGs) [36], Pb concentration was higher than the probable effect level (PEL), whereas $\mathrm{Cu}$ and $\mathrm{Cd}$ concentrations were not exceeded the threshold effect level (TEL). $\mathrm{Pb}$ and $\mathrm{Zn}$ concentrations were particularly high the sediment cores of the elder mangrove forests (DL27 and DL19) (Fig.5). The result had a related with clarification trace metals of the Northern Persian Gulf [12]. Additionally, heavy metals concentrations were compared with the National Technical Regulation on Sediment Quality (QCVN 43:2012/BTNMT).

Results are shown in Table 3. The concentrations of $\mathrm{Cu}$ and $\mathrm{Pb}$ were exceeded the QCVN 43:2012. The present results assumed that the mangrove sediments in the study area could be contaminated by $\mathrm{Cu}$ and $\mathrm{Pb}$. However, this conclusion must be concerned due to the few samples used in this study. In the future study, it should be focused on analyzing the higher resolution of sediment samples and evaluating the heavy metal concentrations in surface sediments of mangrove forests.

\section{Conclusions}

The present results demonstrated that the mangrove sediments were mainly composed of sandy silt, silty sand, silt, sandy mud and mud.
Mud contents of the sediment cores increased following the mangrove forest ages with an order of DL01, DL09, DL19 and DL27 and fluctuated with the depth of sediment cores. The $\mathrm{pH}$, Eh and organic matter contents indicated that the sedimentary depositional environment were weak alkaline and anaerobic. In addition, a significant increase in organic matter content with mangrove forest ages demonstrated that the mangrove litters contributed a major proportion in sedimentary organic matters. Heavy metal concentrations were generally higher in the elder mangrove forests. Based on Canadian interim sediment quality guidelines (ISQGs), $\mathrm{Cu}, \mathrm{Pb}$ were exceed the TEL and PEL level, $\mathrm{Zn}$ was polluted in a moderately contamination level. Additionally, $\mathrm{Cu}$ and $\mathrm{Pb}$ concentration were exceeded the permitted values in the QCVN43:2012/BTNMT. Results from the present study provided a valuable geochemical data for further studies in Da Loc mangrove forests.

\section{Acknowledgements}

The authors are grateful to Dr. Luu Viet Dung and Dr. Pham Van Hieu supported for their help in the field trip. The present study is supported by Vietnam National Project "Research on developing the sustainability index for Vietnam coastal zone, experimental 
applying for important areas and promoting the extended solutions - No. BĐKH.23/16-20".

\section{References}

[1] D. M. Alongi, "Carbon payments for mangrove conservation: Ecosystem constraints and uncertainties of sequestration potential", Environ. Sci. Policy, vol. 14, no. 4, pp. 462470, 2011.

[2] D. M. Alongi, "Mangrove forests: Resilience, protection from tsunamis, and responses to global climate change", Estuar. Coast. Shelf Sci., vol. 76, pp. 1-13, 2008.

[3] M. Lewis, R. Pryor, and L. Wilking, "Fate and effects of anthropogenic chemicals in mangrove ecosystems: A review", Environmental Pollution. pp. 2328-2346, 2011.

[4] Z.-W. Zhang, X.-R. Xu, Y.-X. Sun, S. Yu, Y.-S. Chen, and J.-X. Peng, "Heavy metal and organic contaminants in mangrove ecosystems of China: A review", Environ. Sci. Pollut. Res., vol. 21, no. 20, pp. 11938-11950, 2014.

[5] N. F. Y. Tam and Y. S. Wong, "Retention and distribution of heavy metals in mangrove soils receiving wastewater", Environ. Pollut., 1996.

[6] K. Yunus et al., "Heavy Metal Concentration in the Surface Sediment of Tanjung Lumpur Mangrove Forest, Kuantan, Malaysia”, Sains Malaysiana, vol. 40, no. 2, pp. 89-92, 2011.

[7] N. T. Tue, N. T. Ngoc, T. D. Quy, H. Hamaoka, M. T. Nhuan, and K. Omori, "A cross-system analysis of sedimentary organic carbon in the mangrove ecosystems of Xuan Thuy National Park, Vietnam”, J. Sea Res., 2012.

[8] K. Abou Seedo, M. S. Abido, A. A. Salih, and A. Abahussain, "Assessing Heavy Metals Accumulation in the Leaves and Sediments of Urban Mangroves (Avicennia marina (Forsk.) Vierh.) in Bahrain”, Int. J. Ecol., 2017.

[9] L. H. Defew, J. M. Mair, and H. M. Guzman, "An assessment of metal contamination in mangrove sediments and leaves from Punta Mala Bay, Pacific Panama", Mar. Pollut. Bull., 2005.

[10] S. Costa-Böddeker and C, "Ecological risk assessment of a coastal zone in Southern Vietnam: Spatial distribution and content of heavy metals in water and surface sediments of the Thi Vai Estuary and Can Gio Mangrove Forest", Mar. Pollut. Bull., vol. 114, no. 2, pp. 1141-1151, 2017.

[11] D. D. Kurlapkar and S. D. Shaikh, "Original Research Article Sediment characteristics of mangroves from Bhatey and Kalabadevi Estuary (Maharashtra), India”, Int.J.Curr.Microbiol.App.Sci, vol. 3, no. 6, pp. 449-453, 2014.

[12] H. Agah, H. M.S, and W. Baeyen, "Trace Metals and Major Elements in Sediments of the Northern Persian Gulf', J. Persian Gulf, vol. 3, no. 7, pp. 45-58, 2012.

[13] S. Orchard, L. C. Stringer, and W. P. No, "Exploring mangrove social-ecological system dynamics in South-East Asia: linking livelihoods, vulnerability and ecosystem services in Vietnam", Clim. Chang. Econ. Policy Work. Pap. No.169, no. 169, 2014.

[14] S. E. Orchard, L. C. Stringer, and C. H. Quinn, "Mangrove system dynamics in Southeast Asia: linking livelihoods and ecosystem services in Vietnam", Reg. Environ. Chang., vol. 16, no. 3, pp. 865-879, 2016.

[15] S. E. Orchard, L. C. Stringer, and C. H. Quinn, "Impacts of aquaculture on social networks in the mangrove systems of northern Vietnam", Ocean Coast. Manag., vol. 114, pp. 1-10, 2015.

[16] S. L. T. Hoa, "Adapting to Natural Disasters and Contributing to Climate Change Mitigation: Mangrove Community Forestry in Vietnam", Link. Adapt. Mitig. through Community For. Case Stud. from Asia, p. 80, 2012.

[17] N. T. Tue, L. V. Dung, M. T. Nhuan, and K. Omori, "Carbon storage of a tropical mangrove forest in Mui Ca Mau National Park, Vietnam", Catena, vol. 121, pp. 119-126, 2014.

[18] R. L. Folk, "The Distinction between Grain Size and Mineral Composition in SedimentaryRock Nomenclature", J. Geol., 1954.

[19] Q. Tu, S. Yang, Q. Zhou, and J. Yang, "Sediment transport and carbon sequestration characteristics along mangrove fringed coasts", Acta Oceanol. Sin., vol. 34, no. 2, pp. 21-26, 2015.

[20] M. F. Adame, D. Neil, S. F. Wright, and C. E. Lovelock, "Sedimentation within and among 
mangrove forests along a gradient of geomorphological settings", Estuar. Coast. Shelf Sci., vol. 86, no. 1, pp. 21-30, 2010.

[21] M. D. Hossain and A. A. Nuruddin, "Soil and mangrove: A review", J. Environ. Sci. Technol., vol. 9, no. 2, pp. 198-207, 2016.

[22] V. Hatje, T. E. Payne, D. M. Hill, G. McOrist, G. F. Birch, and R. Szymczak, "Kinetics of trace element uptake and release by particles in estuarine waters: Effects of $\mathrm{pH}$, salinity, and particle loading", Environ. Int., vol. 29, no. 5, pp. 619-629, 2003.

[23] M. Z. Hossain, C. B. Aziz, and M. L. Saha, "Relationships between Soil Physico-Chemical Properties and Total Viable Bacterial Counts in Sunderban Mangrove Forests, Bangladesh", Dhaka Univ. J. Biol. Sci., vol. 21, no. 2, pp. 169-175, 2012.

[24] S. Das, "Depth Integrated Microbial Community and Physico-Chemical Properties in Mangrove Soil of Sundarban, India”, Adv. Microbiol., vol. 2, no. 3, pp. 234-240, 2012.

[25] L. H. N. Cooper, "Oxidation-Reduction Potential in Sea Water", J. Mar. Biol. Assoc. United Kingdom, vol. 22, no. 1, pp. 167-176, 1937.

[26] F. E. S. Ghada and D. H. Youssef, "Ecotoxicological impact assessment of some heavy metals and their distribution in some fractions of mangrove sediments from Red Sea, Egypt", Environ. Monit. Assess., vol. 185, no. 1, pp. 393-404, 2013.

[27] A. R. A. Usman, R. S. Alkredaa, and M. I. AlWabel, "Heavy metal contamination in sediments and mangroves from the coast of Red Sea: Avicennia marina as potential metal bioaccumulator", Ecotoxicol. Environ. Saf., 2013.

[28] G. R. MacFarlane, "Leaf biochemical parameters in Avicennia marina (Forsk.) Vierh as potential biomarkers of heavy metal stress in estuarine ecosystems", Mar. Pollut. Bull., vol. 44, no. 3, pp. 244-256, 2002.
[29] L. Perdomo, I. Ensminger, L. F. Espinosa, and C. Elster, "The Mangrove Ecosystem of the $\mathrm{Ci}$ enaga Grande de Santa Marta ( Colombia ): Observations on Regeneration and Trace Metals in Sediment”, vol. 37, 1999.

[30] S. P. Kumar and J. K. Patterson Edward, "Assessment of metal concentration in the sediment cores of Manakudy estuary, south west coast of India", Indian J. Mar. Sci., vol. 38, no. 2, pp. 235-248, 2009.

[31] R. Chowdhury, P. J. C. Favas, M. P. Jonathan, P. Venkatachalam, P. Raja, and S. K. Sarkar, "Bioremoval of trace metals from rhizosediment by mangrove plants in Indian Sundarban Wetland", Mar. Pollut. Bull., vol. 124, no. 2, pp. 1078-1088, 2017.

[32] S. Caeiro et al., "Assessing heavy metal contamination in Sado Estuary sediment: An index analysis approach", Ecol. Indic., vol. 5, no. 2, pp. 151-169, 2005.

[33] J. Stendahl, B. Berg, and B. D. Lindahl, "Manganese availability is negatively associated with carbon storage in northern coniferous forest humus layers", Sci. Rep., vol. 7, no. 1, pp. 1-6, 2017.

[34] E. P. Nobi, E. Dilipan, T. Thangaradjou, K. Sivakumar, and L. Kannan, "Geochemical and geo-statistical assessment of heavy metal concentration in the sediments of different coastal ecosystems of Andaman Islands, India”, Estuar. Coast. Shelf Sci., vol. 87, no. 2, pp. 253-264, 2010.

[35] K. K. Turekian and K. H. Wedepohl, "Geological Society of America Bulletin Distribution of the Elements in Some Major Units of the Earth's Crust", Geol. Soc. Am. Bull., vol. 72, pp. 175-192, 1961.

[36] Canadian Council of Ministers of the Environment, "Canadian Sediment Quality Guidelines for the Protection of Aquatic Life", Environ. Prot., pp. 1-3, 2001. 


\title{
Hàm lượng kim loại nặng trong các cột trầm tích từ rừng ngập mặn với độ tuổi khác nhau tại xã Đa Lộc, huyện Hậu Lộc, tỉnh Thanh Hóa
}

\author{
Trần Thị Minh ${ }^{1}$, Nguyễn Tài Tuệ ${ }^{2,3}$, Trần Đăng Quy ${ }^{2,3}$, Lee Jong-Un ${ }^{1}$ \\ ${ }^{1}$ Khoa Kỹ thuật Tài nguyên và Năng luợng, Truờng Đại học Quốc gia Chonnam, Gwangju, Hàn Quốc \\ ${ }^{2}$ Khoa Địa chất, Truờng Đại học Khoa học Tự nhiên, 334 Nguyễn Trãi, Thanh Xuân, Hà Nội, Việt Nam \\ ${ }^{3}$ Phòng thi nghiệm trọng điểm về Địa môi truờng và Ứng phó Biến đổi khí hậu, \\ 334 Nguyến Trãi, Thanh Xuân, Hà Nội, Việt Nam
}

Tóm tắt: Để xác định sự tập trung của các kim loại nặng trong các cột trầm tích từ rừng ngập mặn với độ tuổi khác nhau, bốn cột trầm tích với độ sâu $100 \mathrm{~cm}$ đã được thu thập, phân tích các chỉ số hóa lý (pH, Eh, hàm lượng vật chất hữu cơ, thành phần hạt) và hàm lượng kim loại nặng. Kết quả chỉ ra rằng thành phần hạt của các cột trầm tích chủ yếu là cát bột, bột, bột cát, bùn cát và bùn. Hàm lượng bùn trung bình của các cột trầm tích tăng dần từ trầm tích rừng ngập mặn $1,9,19$ và 27 tuổi, trong khi đó lại có biến động lớn theo độ sâu. Giá trị $\mathrm{pH}$, Eh và hàm lượng vật chất hữu cơ chứng tỏ môi trường trầm tích là môi trường kiềm yếu và hiếm khí. Hàm lượng $\mathrm{Cu}$ và $\mathrm{Zn}$ trong các cột trầm tích tại bãi triều Đa Lộc đã vượt giới hạn TEL, hàm lượng $\mathrm{Pb}$ vượt giá trị $\mathrm{PEL}$ cho phép theo tiêu chuẩn trầm tích biển Canada (ISQGs). Khi so sánh với tiêu chuẩn trầm tích của Việt Nam QCVN 43:2012/BTNMT, trầm tích tại khu vực nghiên cứu đã bị ô nhiễm bởi $\mathrm{Cu}$ và $\mathrm{Pb}$.

Từ khóa: Trầm tích rừng ngập mặn, kim loại nặng, bãi triều, Đa Lộc. 